\title{
Phytochemical analysis and evaluation antibacterial activity of Citrus medica peel and juice growing in Kurdistan/Iraq
}

\author{
Aveen Nozad Adham \\ Department of Pharmacognosy, College of Pharmacy, Hawler Medical University, Erbil, Kurdisatn region, Iraq.
}

\begin{tabular}{|c|c|}
\hline ARTICLE INFO & ABSTRACT \\
\hline Article history: & \multirow{7}{*}{$\begin{array}{l}\text { Citrus medica is an important medicinal plant of the family Rutaceae Qualitative and quantitative screening were } \\
\text { performed for evaluation bioactive constituents in Citrus medica fruit. The antibacterial activity of the ethyl } \\
\text { acetate and ethanol } 80 \% \text { peel extracts and juice of Citrus medica was assessed by agar well diffusion assay, } \\
\text { minimum inhibitory concentration (MIC) value determination by } 96 \text { well serial dilution against five gram } \\
\text { positive and two gram negative bacteria, while minimum bactericidal concentration (MBC) evaluated by plate } \\
\text { cultures. Qualitative investigation shows the presence of carbohydrates, flavonoids, phenols, tannins, steroids, } \\
\text { cardioactive glycosides in peel and juice, while saponins, terpenoids, and anthraquinones absent in all fraction of } \\
\text { Citrus medica. On quantitative screening peel contain highest quantity tannin as compared to juice while juice } \\
\text { contain higher quantity phenol and Citrus medica fruits contain high quantity phenol than flavonoids. The juice } \\
\text { of Citrus medica exhibited largest inhibition zone }(12 \mathrm{~mm}) \text { at }(100 \mathrm{mg} / \mathrm{ml}) \text { and recorded the lowest MIC and MBC } \\
\text { value }(1.5625 \mathrm{mg} / \mathrm{ml} \mathrm{\&} 3.125 \mathrm{mg} / \mathrm{ml}) \text { against Staphylococcus auricularis. The ethyl acetate extract of peel } \\
\text { revealed antibacterial activity against four bacterial strain while ethanol } 80 \% \text { only against two bacteria. Peel } \\
\text { extracts exhibited largest inhibition zone }(10 \text { \& } 22 \mathrm{~mm}) \text { at }(100 \mathrm{mg} / \mathrm{ml}) \text { and recorded the lowest MIC value } \\
\text { (25mg/ml \& } 12.5 \mathrm{mg} / \mathrm{ml}) \text { and MBC }(50 \mathrm{mg} / \mathrm{ml}) \text { against Escherichia coli. }\end{array}$} \\
\hline Received on: 04/07/2015 & \\
\hline Revised on: $30 / 07 / 2015$ & \\
\hline Accepted on: 06/08/2015 & \\
\hline Available online: $28 / 10 / 2015$ & \\
\hline Key words: & \\
\hline $\begin{array}{l}\text { Citrus medica, } \\
\text { phytochemical screening, } \\
\text { antibacterial activity, MIC, } \\
\text { MBC. }\end{array}$ & \\
\hline
\end{tabular}

\section{INTRODUCTION}

Genetic ability of bacteria to acquire resistance against antibacterial drugs due to their widely use in medicine, animal and agriculture encourage the search for new antibacterial agents for the establishment alternative therapies against resistant bacteria (Abeysinghe, 2010). Generally Gram negative bacteria are more resistant than Gram positive bacteria (Parekh et al., 2005). Medicinal plant is the most important source for manufacturing different drugs due to their active constituents which are responsible on therapeutic activity because of their structural diversity \& biological functionality constituents which is indispensable for drug discovery (Salih and Abass, 2003). Those constituents can be extracted from different part of plant like barks, leaves, fruits seeds and fruit rinds etc (Parekh and Chanda, 2007). Citrus is one of the most important commercial fruit crops grown in all continents of the world. Among the different species of citrus fruits the Citrus medica is an important medicinal plant of the family Rutaceae which is commonly

\footnotetext{
* Corresponding Author

Email: aveennawzad@yahoo.com
}

known as citron or otroj is an evergreen small tree $(2.4-4.5 \mathrm{~m})$ high, having large fruit $(20-22.5 \mathrm{~cm}$. long) resembling pineapple in shape and mostly grown near the Mediterranean, Iran, Central and South America (Rafiee et al., 2007), India (Anonymous, 2001). Citrus medica traditionally used as an appetizer, carminative, refrigerant, stomachic, tonic, antispasmodic, expectorant, cardiotonic, and induration of the spleen tumors (Hartwell, 1982). Citrus medica peel is eaten raw with rice, also in remedy for dysentery (Fleisher, 1991; Bhuiyan et al., 2009). Citrus medica is relevant to treatment of diabetes and Alzheimer's disease (Filomena, 2007). The plant is reported to possess anthelmintic Activity (Bairagi et al., 2011), antioxidant activity (Al yahya et al., 2013), antimicrobial activity (Kabra et al., 2012), antiinflammatory and pain reducing activity in rats (Sood et al., 2009). The fruit juice exerts antimutagenicity and anticancer effect (Entezari et al., 2009). There are several report on essential oil composition such as limonene, geranial, neral (Theanphong et al., 2008), $\gamma$-terpinene (Shiota, 2006). Citrus medica also known to contain coumarin compounds, p-coumaric acids, steroids, triterpenoids (Feng et al., 2004; Yin and Lou, 2004), scoparone, scopoletin, umbelliferone, vitamin c, citroflavonoids which is hesperidoside, naringoside and ecryodietyoside, in addition to 
glucosides hesperidin and rutin (Sood et al., 2009; Khare, 2007). The aim of this study was to evaluate the activity of the juice and different solvent extract of Citrus medica peels against grampositive and gram-negative isolated bacterial strains in vitro which some of them not previously tested, also active extracts were evaluated for determine their minimum inhibitory concentrations, minimum bactericidal concentration and analysis their bioactive constituents which are responsible for their activity.

\section{MATERIALS AND METHODS}

\section{Collection and extraction of Citrus medica fruits}

Fresh fruits of Citrus medica were collected from garden in Erbil city during June 2015. The plant materials were identified in department of Pharmacognosy, Collage of Pharmacy, Hawler Medical University. Fruits were brought to laboratory washed with sterile distilled water. The peel of fresh fruit removed and 200 $\mathrm{g}$ was weighed then extracted successively with $500 \mathrm{ml}$ ethyl acetate yielding ethyl acetate fraction, the residue dried and reextracted by $80 \%$ ethanol yielding ethanol fraction using ordinary reflex extraction. The extract was filtered using Whatman filter paper (No. 1) and then concentrated in vacuum at $40^{\circ} \mathrm{C}$ using a rotary evaporator. While their juice obtained by hand squeezing the fruits then evaporated to dryness at $40{ }^{\circ} \mathrm{C}$ under vacuum. Peel and juice extract were kept at $4{ }^{\circ} \mathrm{C}$ until used for further study.

\section{Phytochemical screening \\ Qualitative phytochemical screening}

The ethyl acetate, ethanol $80 \%$ peel extracts and juice of Citrus medica were analysed for presence of carbohydrates, alkaloids, flavonoids, phenols, tannins, saponins, steroids, terpenoids, aminoacids, coumarin, anthraquinones, cardioactive glycosides by standard procedures (Tiwari et al., 2011; Sofowra, 1993).

\section{Quantitative phytochemical screening}

\section{Estimation of total phenolic content}

The total phenolic content was determined by the spectrophotometric method (Kim et al., 2003) with slight modification. In brief a $1 \mathrm{ml}$ of ethanol $80 \%$ peel extract and juice were mixed with $1 \mathrm{ml}$ of Folin-Ciocalteu's phenol reagent. After 5 min, $10 \mathrm{ml}$ of a $7 \% \mathrm{Na}_{2} \mathrm{CO}_{3}$ solution was added to the mixture followed by the addition of $13 \mathrm{ml}$ of distilled water and mixed thoroughly. The mixture was kept in the dark for $90 \mathrm{~min}$, after which the absorbance was read at $750 \mathrm{~nm}$. The total phenolic content was determined from extrapolation of calibration curve which was made by preparing gallic acid solution (20-100 $\mu \mathrm{g} / \mathrm{GA}$ and expressed as $(\mu \mathrm{g} \mathrm{GA} / \mathrm{g})$ of dried extract.

\section{Estimation of total flavonoids content}

The total flavonoids content of Citrus medica peel and juice was estimated by method described by (Zhishen et al., 1999) with slight modification. A volume of $(1 \mathrm{ml})$ of ethanol $80 \%$ peel extract and juice were mixed with $4 \mathrm{ml}$ of distilled water and subsequently with $0.30 \mathrm{ml}$ of a $\mathrm{NaNO}_{2}$ solution $(10 \%)$. After 5 min, $0.30 \mathrm{ml} \mathrm{AlCl} 3$ solution (10\%) was added fallowed by $2.0 \mathrm{ml}$ of $\mathrm{NaOH}$ solution $(5 \%)$ to the mixture. Immediately, the mixture was thoroughly mixed and absorbance was then determined at 510 $\mathrm{nm}$ versus the blank. Standard curve of quercetin was prepared $(20-100 \mu \mathrm{g} / \mathrm{ml})$ and the results expressed as quercetin equivalents ( $\mu \mathrm{g}$ quercetin/g dried extract).

\section{Estimation of total tannins content}

The tannin content was determined using Folin-Ciocalteu assay (Tamilselvi et al., 2012) with slight modification. A volume of $100 \mu \mathrm{L}$ of ethanol $80 \%$ peel extract and juice were added to 750 $\mu \mathrm{L}$ of distilled water, $500 \mu \mathrm{L}$ Folin-Ciocateu reagent and $1000 \mu \mathrm{L}$ of $35 \%$ sodium carbonate $\left(\mathrm{Na}_{2} \mathrm{CO}_{3}\right)$. The mixture was shaken vigorously after diluting to $10 \mathrm{~mL}$ of distilled water, then incubated for $30 \mathrm{~min}$ at room temperature and read at $725 \mathrm{~nm}$ using Genway 6305 UV-Vis spectrophotometer. Distilled water was used as blank. The total tannins content was calculated from the prepared standard curve with $20-100 \mu \mathrm{g} / \mathrm{GA}$ and expressed as $(\mu \mathrm{g} \mathrm{GA} / \mathrm{g})$ dry extract.

\section{Antibacterial activity assay \\ Bacterial strain and growth condition}

The antibacterial activity of peel extracts and juice were assessed against seven bacteria species in which five gram positive Staphylococcus aureus, Staphylococcus auricularis, Streptococcus mitis, Streptococcus salivarius, Streptococcus pneumoniae and two gram negative Klebseilla pneumoniae, Escherichia coli. The isolated pathogenic bacteria were used in this work identified and confirmed after morphological studies and by using biochemical tests in the Microbiological Laboratory of the Biological department, Collage Of Education, Salahadin University. All bacteria were grown on Muller Hinton and blood agar at $37^{\circ} \mathrm{C}$ for $24 \mathrm{~h}$, and then stored at $4{ }^{\circ} \mathrm{C}$ until used.

\section{Agar well diffusion method}

The antibacterial activity of peel (Ethyl acetate and 80\% ethanol extracts) and juice of Citrus medica against seven isolated pathogenic bacteria was evaluated by using agar well diffusion method (Ahmad and Beg, 2001; Srinivasan et al., 2001) with slight modification. Petridish were inoculated with $100 \mu 1$ of standardized inoculum bacterium and spread with sterile swabs. $6 \mathrm{~mm}$ wells were made with sterile borer into Muller Hinton agar plates containing the bacterial inoculum. 50 $\mu 1$ volume of the peel extracts and juice were poured into a well of inoculated plates. DMSO and Tween 80 were used as a negative control which was introduced into a well instead of fruit extract. Commercially available standard antibiotics (Chloramphenical and bacitracin) as a positive control for comparative study. The plates were incubated for $24 \mathrm{hrs}$ at $37{ }^{\circ} \mathrm{C}$, following incubation the plates were observed. The diameter of inhibition zone (DIZ) was measured and expressed in millimeters. The mean values of the diameter of inhibition zones were calculated. 


\section{Determination of minimum inhibitory and minimum bactericidal concentration}

The minimum inhibitory concentration (MIC) for the peel extracts and juice were estimated using 96- flat well microtiter broth dilution method. The test was performed in sterile 96 well. All the extracts were dissolved in 10\% DMSO and 20\% Tween then the two folds serial dilution of products was added to the wells, starting from $100 \mathrm{mg} / \mathrm{ml}$ as higher active concentration. Around $10 \mu$ bacterial suspensions adjusted to $0.5 \mathrm{McFarland}$ turbidity were added. Bacterial suspension were used as growth control, broth as a sterility control. The plates were covered and incubated for $24 \mathrm{hr}$ at $37{ }^{\circ} \mathrm{C}$. After that $30 \mu \mathrm{l}$ of 3- (4, 5-dimethylthiazol-2-yl)-2,5-diphenyl-tetrazolium bromide (MTT) at a final concentration $0.5 \mathrm{mg} / \mathrm{ml}$ freshly prepared in water was added to each well and incubated for $30 \mathrm{~min}$. The change to violet colour indicated that the bacteria were biologically active. The MIC was taken to the well, where no change of colour of MTT was observed. While minimum bactericidal concentration (MBC) of extract were determined by sub-culturing the wells that showed nonturbid only. Following incubation for $24 \mathrm{~h}$ at $370 \mathrm{C}$ the concentration of extract that does not showing bacterial growth after sub-culturing considered as MBC (Umeh et al., 2005; Basri and Fan, 2005).

\section{Statistical analysis}

All procedures for antibacterial activity were repeated at least three times and the mean value and calibration curve for quantitative screening were estimated using Microsoft Excel 2007.

\section{RESULTS}

The phytochemical characteristics of peel extracts and juice of Citrus medica studied were summarized in (table 1) the results revealed presence of carbohydrates, flavonoids, phenols, tannins, steroids, cardioactive glycosides in peel extracts and juice, while saponins, terpenoids, and anthraquinones abscent in all fraction of Citrus medica.

Table 1: Qualitative phytochemical screening of peel and juice of Citrus medica.

\begin{tabular}{lccc}
\hline \multirow{2}{*}{ Chemical tests } & \multicolumn{2}{c}{ Citrus medica peel } & Citrus medica \\
\cline { 2 - 3 } & Ethyl acetate & Ethanol 80\% & Juice \\
\hline Carbohydrates & $+\mathrm{Ve}$ & $+\mathrm{Ve}$ & $+\mathrm{Ve}$ \\
Alkaloids & $-\mathrm{Ve}$ & $-\mathrm{Ve}$ & $+\mathrm{Ve}$ \\
Flavonoids & $+\mathrm{Ve}$ & $+\mathrm{Ve}$ & $+\mathrm{Ve}$ \\
Phenols & $+\mathrm{Ve}$ & $+\mathrm{Ve}$ & $+\mathrm{Ve}$ \\
Tannins & $+\mathrm{Ve}$ & $+\mathrm{Ve}$ & $+\mathrm{Ve}$ \\
Saponins & $-\mathrm{Ve}$ & $-\mathrm{Ve}$ & $-\mathrm{Ve}$ \\
Steroids & $+\mathrm{Ve}$ & $+\mathrm{Ve}$ & $+\mathrm{Ve}$ \\
Terpenoids & $-\mathrm{Ve}$ & $-\mathrm{Ve}$ & $-\mathrm{Ve}$ \\
Aminoacids & $-\mathrm{Ve}$ & $+\mathrm{Ve}$ & $+\mathrm{Ve}$ \\
Coumarin & $+\mathrm{Ve}$ & $+\mathrm{Ve}$ & $-\mathrm{Ve}$ \\
Anthraquinones & $-\mathrm{Ve}$ & $-\mathrm{Ve}$ & $-\mathrm{Ve}$ \\
Cardioactive glycosides & $+\mathrm{Ve}$ & $+\mathrm{Ve}$ & $+\mathrm{Ve}$ \\
\hline +Ve: Presence $;-\mathrm{Ve}:$ Abscence & &
\end{tabular}

Alkaloids only present in juice, amino acids in juice and $80 \%$ ethanol fraction of peel, coumarin present in ethyl acetate and
$80 \%$ ethanol fraction of peel. The results of quantitative screening are shown in (table 2, figure 1-3) were expressed as mg/g of dry extract revealed that different amount of bioactive constituents present in peel and juice of Citrus medica.

Table 2: Total phenolic, flavonoid and tannin content in peel and juice of Citrus medica.

\begin{tabular}{lll}
\hline Phytochemicals & Peel & Juice \\
\hline Total phenolic content (mg/g of dry extract) & 21.18 & 9.38 \\
Total flavonoid content (mg/g of dry extract) & 4.59 & 1.44 \\
Total tannin content (mg/g of dry extract) & 32.20 & 8.3 \\
\hline
\end{tabular}

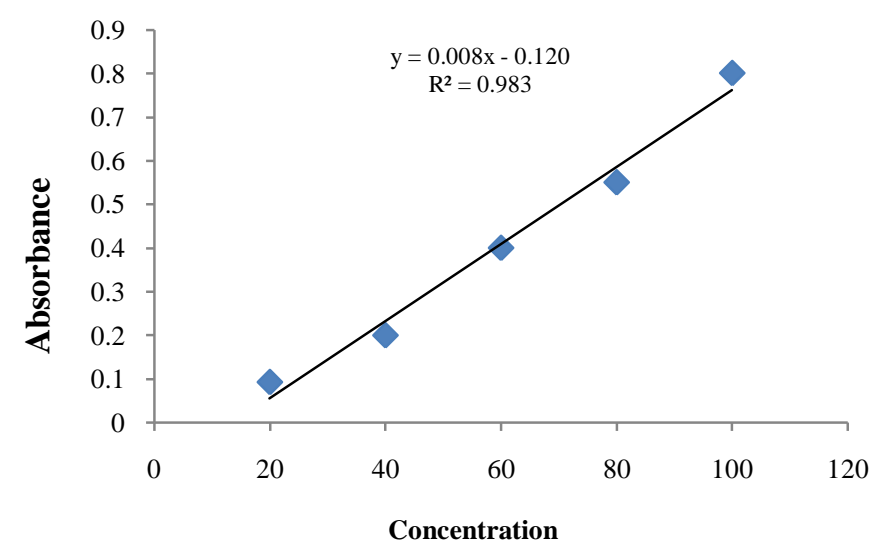

Fig. 1: Linear regression plots and correlation coefficients of total phenols contents of Citrus medica.

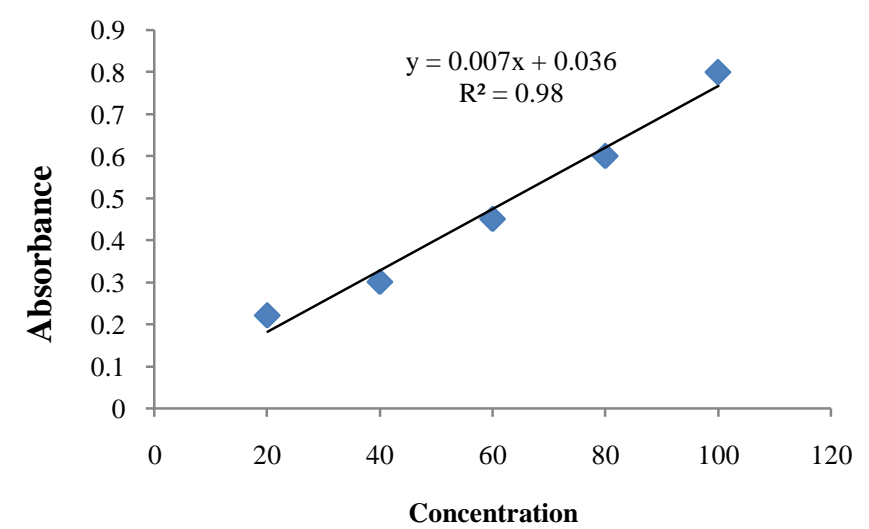

Fig. 2: Linear regression plots and correlation coefficients of total flavonoid contents of Citrus medica.

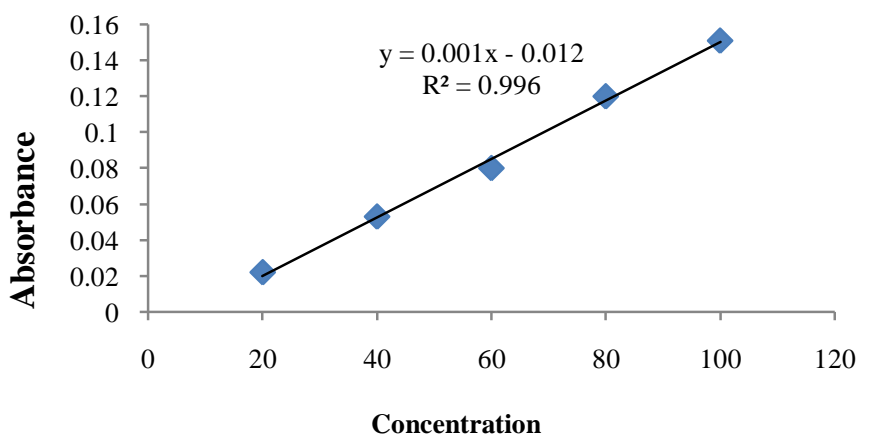

Fig. 3: Linear regression plots and correlation coefficients of total tannin contents of Citrus medica. 
Table 3: In vitro antibacterial activity of peel extracts and juice of Citrus medica.

\begin{tabular}{|c|c|c|c|c|c|c|c|c|c|c|c|}
\hline \multicolumn{12}{|c|}{ Diameter of inhibition zone (DIZ) in $\mathrm{mm}$} \\
\hline \multirow[t]{2}{*}{ Bacteria } & \multicolumn{3}{|c|}{ E a (mg/ml) } & \multicolumn{3}{|c|}{ E $80 \%(\mathrm{mg} / \mathrm{ml})$} & \multicolumn{3}{|c|}{$\mathbf{J}(\mathbf{m g} / \mathbf{m l})$} & \multirow{2}{*}{$\begin{array}{l}\text { Chloram. } \\
10 \mu \mathrm{g} / \mathrm{ml}\end{array}$} & \multirow{2}{*}{$\begin{array}{l}\text { Bacitr. } \\
10 \mu \mathrm{g} / \mathrm{ml}\end{array}$} \\
\hline & 400 & 200 & 100 & 400 & 200 & 100 & 400 & 200 & 100 & & \\
\hline \multicolumn{12}{|l|}{ Bacterial strains G (+) } \\
\hline Staphylococcus aureus & 10 & 7 & $\mathrm{R}$ & $\mathrm{R}$ & $\mathrm{R}$ & $\mathrm{R}$ & 16 & 10 & $\mathrm{R}$ & 18 & 5 \\
\hline Staphylococcus auricularis & $\mathrm{R}$ & $\mathrm{R}$ & $\mathrm{R}$ & 10 & $\mathrm{R}$ & $\mathrm{R}$ & 23 & 15 & 12 & 15 & 15 \\
\hline Streptococcus mitis & $\mathrm{R}$ & $\mathrm{R}$ & $\mathrm{R}$ & $\mathrm{R}$ & $\mathrm{R}$ & $\mathrm{R}$ & 20 & 13 & 10 & 25 & 25 \\
\hline Streptococcus salivarius & $\mathrm{R}$ & $\mathrm{R}$ & $\mathrm{R}$ & $\mathrm{R}$ & $\mathrm{R}$ & $\mathrm{R}$ & $\mathrm{R}$ & $\mathrm{R}$ & $\mathrm{R}$ & 10 & $\mathrm{R}$ \\
\hline Streptococcus pneumoniae & 7 & 3 & $\mathrm{R}$ & $\mathrm{R}$ & $\mathrm{R}$ & $\mathrm{R}$ & 16 & 14 & 10 & 17 & $\mathrm{R}$ \\
\hline \multicolumn{12}{|l|}{ Bacterial strain G (-) } \\
\hline Klebseilla pneumoniae & 7 & 6 & 3 & $\mathrm{R}$ & $\mathrm{R}$ & $\mathrm{R}$ & 13 & 10 & 7 & 10 & $\mathrm{R}$ \\
\hline Escherichia coli & 15 & 13 & 10 & 35 & 30 & 22 & $\mathrm{R}$ & $\mathrm{R}$ & $\mathrm{R}$ & 25 & $\mathrm{R}$ \\
\hline
\end{tabular}

E a: Ethyl acetate extract; E 80\%: Ethanol 80\% extract; J: Juice; Chloram.: Chloramphenicol; Bacitr.: Bacitracin; R: Resistance.

Table 4: Determination of MIC and MBC of peel extracts and juice of Citrus medica

\begin{tabular}{|c|c|c|c|c|c|c|}
\hline \multirow[t]{2}{*}{ Bacteria } & \multicolumn{3}{|c|}{ MIC (mg/ml) } & \multicolumn{3}{|c|}{ MBC (mg/ml) } \\
\hline & $\mathbf{E} \mathbf{a}$ & E $80 \%$ & $\mathbf{J}$ & $\mathbf{E} \mathbf{a}$ & E 80\% & $\mathbf{J}$ \\
\hline \multicolumn{7}{|l|}{ Bacterial strain G (+) } \\
\hline Staphylococcus auricularis & -- & -- & 1.5625 & -- & -- & 3.125 \\
\hline Streptococcus mitis & -- & -- & 6.25 & -- & -- & 12.5 \\
\hline Streptococcus pneumoniae & -- & -- & 6.25 & -- & -- & 25 \\
\hline \multicolumn{7}{|l|}{ Bacterial strain G (-) } \\
\hline Klebseilla pneumoniae & 12.5 & -- & 3.125 & 25 & -- & 6.25 \\
\hline Escherichia coli & 25 & 12.5 & -- & 50 & 50 & -- \\
\hline
\end{tabular}

The ethanolic $80 \%$ extract of peel was highest tannin content $(32.2 \mathrm{mg} / \mathrm{g})$ followed by phenolic $(21.18 \mathrm{mg} / \mathrm{g})$ and flavonoid contents $(4.59 \mathrm{mg} / \mathrm{g})$, while juice contain high quantity phenol $(9.38 \mathrm{mg} / \mathrm{g})$, tannin $(8.3 \mathrm{mg} / \mathrm{g})$ then flavonoid $(1.44 \mathrm{mg} / \mathrm{g})$. The antibacterial activities of Citrus medica against seven isolated bacterial strains examined in the present study and their potency were qualitatively and quantitatively assessed by the presence or absence of inhibition zones and zone diameter by agar well diffusion, MIC and MBC values. The ethyl acetate, ethanol $80 \%$ peel extracts and juice showed varied antibacterial activity against the studied isolates gram positive and gram negative bacteria. As can be seen from (table 3) ethyl acetate extract exhibited highest antibacterial activity $(10 \mathrm{~mm})$ against Escherichia coli, followed by $(3 \mathrm{~mm})$ against Klebseilla pneumoniae at $(100 \mathrm{mg} / \mathrm{ml})$ and $(7$ $\mathrm{mm} \& 3 \mathrm{~mm}$ ) against Staphylococcus aureus and Streptococcus pneumoniae at $(200 \mathrm{mg} / \mathrm{ml})$ while showed no activity against the other bacteria even at $(400 \mathrm{mg} / \mathrm{ml})$. The minimum inhibitory effect of ethyl acetate was recorded against Klebseilla pneumoniae and Escherichia coli $(12.5 \& 25 \mathrm{mg} / \mathrm{ml})$ and minimum bactericidal concentration was $(25 \& 50 \mathrm{mg} / \mathrm{ml})$ respectively (table 4$)$. The ethanol $80 \%$ extract also shown highest antibacterial activity at minimum concentration $100 \mathrm{mg} / \mathrm{ml}$ against Escherichia coli $(22 \mathrm{~mm})$, followed by $(10 \mathrm{~mm})$ against Staphylococcus auricularis at $(400 \mathrm{mg} / \mathrm{ml})$ and not exhibited activity against other bacteria. The minimum inhibitory effect of ethanol $80 \%$ was recorded against Escherichia coli $(12.5 \mathrm{mg} / \mathrm{ml})$ and minimum bactericidal concentration was $(50 \mathrm{mg} / \mathrm{ml})$. The results of juice have shown some variation, the high antibacterial activity at $(100 \mathrm{mg} / \mathrm{ml})$ was revealed against Staphylococcus auricularis $(12 \mathrm{~mm})$, followed by Streptococcus mitis, Streptococcus pneumoniae $(10 \mathrm{~mm})$ and Klebseilla pneumoniae $(7 \mathrm{~mm})$, then against Staphylococcus aureus $(10 \mathrm{~mm})$ at $(200 \mathrm{mg} / \mathrm{ml})$ and not showed any activity against other bacteria. The minimum inhibitory effect of juice was recorded against Staphylococcus auricularis $(1.5625 \mathrm{mg} / \mathrm{ml})$ with MBC $(3.125 \mathrm{mg} / \mathrm{ml})$, followed by Klebseilla pneumoniae $(3.125 \mathrm{mg} / \mathrm{ml})$ with $\mathrm{MBC}(6.25 \mathrm{mg} / \mathrm{ml})$ then Streptococcus mitis, Streptococcus pneumoniae $(6.25 \mathrm{mg} / \mathrm{ml})$ with $\mathrm{MBC}(12.5 \& 25$ $\mathrm{mg} / \mathrm{ml}$ ) respectively.

\section{DISCUSSION}

Plants and herbal remedies are source most important bioactive constituent should be investigated for their antibacterial activity for finding novel antibacterial drugs with less adverse effect and high ability to kill gram positive and gram negative bacteria (Nascimento et al., 2000). Bioactive constituent of plant are non-nutritive posses specific chemicals structure help in their disease preventive and antimicrobial activities and work with different mechanism of action (Panda and Bandyopadhyay, 2013). Results of qualitative phytochemical screening in (table 1) clearly demonstrated the presence of number important active constituents. Presence of carbohydrates, flavonoids, phenols, steroids and absence of saponins, anthraquinones, coumarin in Citrus medica in agreement with previously recorded data (Kabra et al., 2012; Chan et al., 2010), while presence of tannins, cardioactive glycosides in peel and juice and absence of alkaloids in peel of Iraqi species in contrast to the same study (Kabra et al., 2012) . The quantitative determination of plant bioactive constituents in this study the results showed in (table 2) revealed that phenolic content $(21.18 \& 9.38 \mathrm{mg} / \mathrm{g}$ dry extract $)$ in Citrus medica was higher than flavonoid content $(4.59 \& 1.44 \mathrm{mg} / \mathrm{g}$ dry extract) in peel and juice respectively are in accordance with those carried out in Riyadh, Saudi Arabia in which Citrus medica fruits showed high total phenol content (192.4 mg GA /100 g) than flavonoid values (74.1 mg quercetin /100 g) (Al-Yahya et al., 2013). while their levels in this study are much higher than those 
measured in Citrus medica from Riyadh indicating that the contents can be influenced by several factors like extraction methods, harvest time, genotypic differences, geographical and climatic conditions and cultural practices (Vander et al., 2001). Quantitative estimation of tannin in Citrus medica not previously recorded. In this study the antibacterial activity of peel extracts and juice against five gram positive and two gram negative bacteria was evaluated. The diameter of inhibition zone was measured by agar well diffusion assay are presented in (table 3 ). The results indicated that juice showed antibacterial activity against five bacterial strain followed by ethyl acetate fraction against four bacterial strain then ethanol $80 \%$ fraction only against two bacterial strain.

The antibacterial activities of peel extracts and juice varied with the type of test organism. Peel extracts revealed stronger activity against gram negative when compared to gram positive bacteria while juice have stronger activity against gram positive than gram negative bacteria. Escherichia coli highly inhibited by peel extracts as largest zone of inhibitions were obtained. Gram positive bacteria Staphylococcus auricularis, Streptococcus mitis, Streptococcus pneumoniae showed complete sensitivity against juice of Citrus medica obvious zone of inhibition. While Streptococcus salivarius demonstrated the complete resistance against juice and peel extracts of Citrus medica among all the bacterial species examined in this study (table 3). The antibacterial activity Citrus medica against, Staphylococcus auricularis, Streptococcus mitis, Streptococcus salivarius, Streptococcus pneumoniae has not been previously described. The antibacterial activity of semi-polar solvent extract of Citrus medica against Klebseilla pneumoniae, Escherichia coli and Staphylococcus aureus and ethanolic extract activity against Escherichia coli in agreement with the study conducted by (Tumane et al., 2014).

Also Kabra et al., 2012 reported that ethanolic extract of Citrus medica showed antibacterial activity when tested against Klebseilla pneumoniae, Escherichia coli and Staphylococcus aureus. These results are in accordance to the results obtained in the present study about activity against Escherichia coli while in contrast for Klebseilla pneumoniae and Staphylococcus aureus. Negative control using DMSO and Tween 80 used for extract preparation showed no inhibition of any bacteria, indicating that peel and juice itself and not solvent inhibited the growth of bacteria. Chloramphenicol and bacitracin (a positive control) showed variable inhibition diameters ranging from $(10-25 \mathrm{~mm}$ and $5-25 \mathrm{~mm}$ ) respectively. Bacitracin showed activity only against three gram positive bacteria. The MIC determined by broth micro dilution method in which gram positive bacteria most susceptible to Citrus medica present with lower MIC value than gram negative bacteria.

The high sensitivity of gram positive bacteria may be due to phytoconstituents present in Citrus medica which inhibit peptidoglycan synthesis in gram positive bacteria, or may be related to a strong permeability barrier of outer surface gram negative bacteria which due to an outer phospholipidic membrane carrying the structural lipopolysaccharide components which cannot be found in gram positive bacteria (Nostro et al., 2000). The lowest MIC value was for juice $(1.5625 \mathrm{mg} / \mathrm{ml})$ with MBC $(3.125 \mathrm{mg} / \mathrm{ml})$ against Staphylococcus auricularis and the highest MIC value for ethyl acetate extract $(25 \mathrm{mg} / \mathrm{ml})$ against Escherichia coli with MBC $(50 \mathrm{mg} / \mathrm{ml})$ (table 4$)$. Surprisingly, ethyl acetate extract have larger inhibition zones and higher MIC value against Escherichia coli in compared to Klebseilla pneumoniae; this can be probably due to the presence of compounds in this extract which are difficult to spread on the agar surface, but when they are diluted in agar present a high antibacterial activity. As a result concluded that the antibacterial activity of Citrus medica due to their bioactive constituent present in it because phenolic acid, tannins, flavonoid (Marjorie, 1996), alkaloids (Okwu and Okwu, 2004), steroids (Raquel, 2007) have been reported to have antibacterial properties.

\section{CONCLUSION}

The results demonstrated the presence of bioactive constituents in peel and juice of Citrus medica including phenols, tannins, flavonoids, cardioactive glycosides, alkaloids, steroids, and coumarins. Peel extract revealed stronger activity against gram negative while juice have stronger activity against gram positive bacteria. juice showed antibacterial activity against five bacterial strain followed by ethyl acetate fraction against four bacterial strain then ethanol $80 \%$ fraction only against two bacterial strain. The antibacterial activity of peel and juice of Citrus medica due to the bioactive constituents present in it.

\section{ACKNOWLEDGEMENT}

The authors are gratefully acknowledging the financial support of department of pharmacognosy, college of pharmacy, Hawler Medical University.

\section{REFERENCES}

Abeysinghe PD. Antibacterial Activity of some medicinal Mangroves against antibiotic resistant pathogenic bacteria. Indian J Pharm Sci, 2010; 72(2): 167-172.

Ahmad I, Beg AZ. Antimicrobial and phytochemical studies on 45 Indian medicinal plants against multidrug resistant human pathogens. J Ethnopharmocol, 2001; 74: 113-123.

Al-Yahya AM, Mothana AR, Al-Said SM, El-Tahir EK, AlSohaibani M, Rafatullah S. Citrus medica "Otroj": Attenuates oxidative stress and cardiac dysrhythmia in isoproterenol-induced cardiomyopathy in rats. Nutrients, 2013; 5(11): 4269-4283.

Ananymous. 2001. The Ayurvedic Pharmacopoeia of India, Part I, Vol III. Govt of India, New Delhi, p. 27-28.

Bairagi GB, Kabra AO, Mandade RJ. Anthelmintic activity of Citrus medica L. leaves in Indian Adult Earthworm. Int J PharmTech Res, 2011; 3(2): 664-667.

Basri DF, Fan SH. The potential of aqueous and acetone extracts of galls of Quercus infectoria as antibacterial agents. Indian J Pharmacol, 2005; 37(1): 26-29.

Bhuiyan INM, Begum J, Sardar KP, Rahman SM. Constituents of peel and leaf essential oils of Citrus medica L. J Sci Res, 2009; 1(2): 387-392. 
Chan YY, Li CH, Shen YC, Wu TS. Anti-inflammatory principles from the stem and root barks of Citrus medica. Chem Pharm Bull, 2010; 58(1): 61-5.

Entezari MA, Majd F, Falahian S., Mehrabian M, Hashemi A, Lajimi A. Antimutagenicity and anticancer effects of Citrus medica L. fruit juice. Acta Med Iran, 2009; 47(5): 373-377.

Feng Y, Cheng L, Liang C. Studies on the constituents of Citrus medica L. var. sarcodactylis (Noot.) Swingle. Chin J Nat Med, 2004; 2: 149-51.

Filomena C, Giancarlo AS, Rosa T, Monica RL, Francesco M. In vitro activities of Citrus medica L. cv. Diamante (Diamante citron) relevant to treatment of diabetes and Alzheimer's disease. Phytotherapy Res, 2007; 21(5): 427.

Fleisher Z, Fleisher A. Aromatic plants of the Holy Land and the Sinai. The essential oil of etrogen. J Essent Oil Res, 1991; 3 (5): $377-$ 379.

Hartwell JL. 1982. Plants Used Against Cancer, a Survey; Quarterman Publications, Inc.: Lawrence, MA, USA, p. 154.

Kabra AO, Bairagi GB, Mahamuni AS, Wanare RS. In vitro antimicrobial activity and phytochemical analysis of the peels of Citrus medica L. Int J Res Pharm Biomed Sci, 2012; 3 (1): 34-37. USA, p. 156.

Khare CP. 2007. Indian medicinal plants, Springer, New York,

Kim DO, Jeong SW, Lee CY. Antioxidant capacity of phenolic phytochemicals from various cultivars of plums. Food Chem, 2003; 81: 321-326.

Marjorie C. Plant products as antimicrobial agents. Clincal Microbiol Rev, 1996; 12: 564-582.

Nascimento GG, Locatelli J, Freitas PC, Silva GL. Antibacterial activity of plant extracts and phytochemicals on antibiotic resistant bacteria. Braz J Microbiol 2000; 31: 247-256.

Nostro A, Germanò M, D'Angelo V, Marino A, Cannatelli M. Extraction methods ans bioautography for evaluation of medicinal plant antimicrobial activity. Lett Appl Microbiol, 2000; 20: 379-84.

Okwu DE, Okw, ME. Chemical composition of Spondias mombin linn. plant parts. J Sustain Agric Environ, 2004; 6(2): 140-147.

Panda S, Bandyopadhyay PK. Chemical information from GCMS studies of methanolic leaf extract of Andrographis paniculata and Datura metel and their antibacterial activity against isolated pseudomonas aeruginosa (pb112) strain. Int J Adv Pharm Biol Sci, 2013; 4(1): 909 - 15.

Parekh J, Chanda S. Antibacterial and phytochemical studies on twelve species of Indian medicinal plants. Afr J of Biomed Res, 2007; 10: $175-181$.

Parekh J, Nair R, Chanda S. Preliminary screening of some folklore medicinal plants from western India for potential antimicrobial activity. Indian J Pharmacol, 2005; 37: 408-409.

Rafiee S, Jahromi KM, Jafari A, Sharifi M, Mirasheh R, Mobli H. Determining some physical properties of bergamot Citrus medica. Int Agrophysics, 2007; 21: 293-297.
Raquel FE. Bacterial lipid composition and antimicrobial efficacy of cationic steroid coppounds. Biochem Biophys Acta, 2007; 2500-2509.

Salih HALM, Abass MA. Study of the fruit peels of Citrus sinesis \& Punica granatum. J Babylon Univ, 2003; 3(9): 243-342.

Shiota H. Volatile components in the peel oil from fingered citron (Citrus medica L. var. sarcodactylis Swingle). Flavour Fragrance J, 2006; 5: 33-37.

Sofowra A. 1993. Medicinal Plants And traditional Medicine In Africa. Spectrum Books Ltd., Ibadan, Nigeria, p.191-289.

Sood S, Bansal S, Muthuraman A, Gill NS, Bali M. Therapeutic potential of Citrus medica L. peel extract in carrageenan induced inflammatory pain in rat. Res J Med Plant, 2009; 3: 123-133.

Srinivasan D, Nathan S, Suresh T, Perumalsamy O. Antimicrobial activity of certain Indian medicinal plants used in folkloric medicine. J Ethnopharmocol, 2001; 74: 217-220.

Tamilselvi P, Krishnamoorthy R, Dhamotharan P, Arumugam E, Sagadevan. Analysis of total phenols, total tannins and screening of phytocomponents in Indigofera aspalathoides (Shivanar Vembu) Vahl EX DC. J Chem Pharm Res, 2012; 4: 3259-3262.

Theanphong $\mathrm{O}$, Songsak $\mathrm{T}$ Mingvanish W. Chemical composition and antimicrobial activity of the essestial oil from Citrus medica L. var. sarcodactylis (Sieber) Swingle Leaf. Mahidol Univ J Pharm Sci, 2008; 35(1-4): 57-61.

Tiwari P, Kumar B, Kaur M, Kaur G, Kaur H. Phytochemical screening and extraction: A Review. Int Pharm Sci, 2011; 1 (1): 98-106.

Tumane PM, Meshram VG, Wasnik DD. Comparative study of antibacterial activity of peel extracts of Citrus aurantium $l$. (bitter orange) and Citrus medica $l$. (lemon) against clinical isolates from wound infection. Int J Pharm Bio Sci, 2014; 5(1): 382 - 387

Umeh EU, Oluma HOA, Igoli O. Antibacterial screening of four local plants using an indicator-based microdilution technique. Afr J Tradit Complement Altern Med, 2005; 2(3): 238-243.

Vander SAA, Dekker M, De Jager A, Jongen WMF. Activity and concentration of polyphenolic antioxidants in apple: effect of cultivar, harvest year, and storage conditions. J Agric Food Chem, 2001; 49: 36063613 .

Yin F, Lou F. Studies on the constituent of Citrus medica L var. sarcodactylis. Zhongguo Yaoxue Zazhi, 2004; 39: 1-20.

Zhishen J, Mengcheng T, Jianming W. The determination of flavonoid contents in mulberry and their scavenging effects on superoxide radicals. Food Chem, 1999; 64(4): 555-559.

\section{How to cite this article:}

Aveen Nozad Adham. Phytochemical analysis and evaluation antibacterial activity of Citrus medica peel and juice growing in Kurdistan/Iraq. J App Pharm Sci, 2015; 5 (10): 136-141. 